\title{
ROLE OF P-SELECTIN IN PATIENTS WITH SLOW CORONARY FLOW
}

\author{
Nahla I. El-Attar ${ }^{1}$, Azaa mohyiAssal ${ }^{1}$, Mohamed E. Amin ${ }^{2}$ and Rowida M.S. Sleem ${ }^{1}$ \\ ${ }^{1}$ Clinical Pathology Department, Faculty of Medicine, Zagazig University \\ ${ }^{2}$ Cardiology Department, Faculty of Medicine, Zagazig University
}

\begin{abstract}
Received: 10 October 2018
Accepted: 28 December 2018

Corresponding author

01001614346

salahrowida@gmail.com
\end{abstract}

\section{ABSTRACT}

Background: sP-selectin is a marker for atherosclerosis and inflammation. It provides prognostic information on cardiovascular events, as reported in the literature. The aim of the present study was to evaluate sP-selectin as a biomarker for cardiovascular mortality in an elderly primary healthcare population, with a focus on possible sex differences

Objective: To evaluate role of $\mathrm{P}$-selectin as a marker of platelets activation in coronary slow flow patients.

patients: A case control study, where seventy two patients underwent cardiac catheterization for suspected coronary artery disease. There were divided into patients group (primary coronary slow flow patients) and controlgroup(normalcoronaryangiography)

Methods:All patients were subjected to history ,physical examination and laboratort investigation included $\mathrm{CBC}$ serum glucose,lipid profile and immunophenotyping of platelets activation( $p$ selectin $C D \quad 62 p$ by flowcytometery).

Results: We have two groups: Group1 (patients group): Patients with primary coronary slow flow phenomenon $=36$ patients. Mean age of cases $49.33 \pm 4.99$ years with range of (34-55) years .In patients group there was 24 male and 12 female. Group II (control group): Patients with normal coronary angiography $=36$ patients. Mean age in control group 51.44 \pm 3.36 years with range of (43-55) years.

Conclusion: The results of the present study revealed that there is very high statistically significant difference in P-selectin level between group 1 (primary coronary slow flow patients) and group 2 (normal coronary angio patients) and there is statistically significant association between P-selectin and TIMI frame count in coronary slow flow.

Key words; P-selectin, Slow coronary flow, platelets, hypercholesterolemia, antioxidants.

\section{INTRODUCTION}

T The coronary slow flow phenomenon (CSFP) is an angiographic clinical entity, characterized by delayed distal vessel opacification in the absence of significant epicardial coronary stenosis ${ }^{[1]}$.

The overall incidence of CSFP is $1 \%$ among patients who undergo coronary angiography, especially those presenting with acute coronary syndrome ${ }^{[2]}$.

Several hypotheses of its mechanism including a form of early phase of atherosclerosis, micro vessel dysfunction, Hagen-poiseuille's equation, imbalance between vasoconstrictor and vasodilator factors, and platelet function disorder were proposed ${ }^{[3]}$.

Platelets play a crucial role in the pathogenesis of atherosclerotic complications, contributing to thrombus formation after plaque rupture $^{[4]}$.

$\mathrm{P}$-selectin is normally stored in the $\alpha$-granules of platelets and the Weibel-Palade bodies of endothelial cells. upon thrombogenic and inflammatory challenges, P-selectin is rapidly expressed, by exocytosis, on the cell surfaces of activated platelets and stimulated endothelial cell ${ }^{[5]}$.

Subsequent to platelet activation, exposed Pselectin can bind with P-selectin glycoprotein ligand-1 (PSGL-1) of monocytes. These aggregates can further enhance activation of monocyte, facilitating activation of inflammation and thrombosis. Platelet rolling and platelet endothelial adhesion are also mediated by $\mathrm{P}$-selectin expression upon platelet activation ${ }^{[6]}$. 
P-selectin, expressed on the activated platelets, has been found to have a prominent role in stabilization of platelet aggregates and in size determination of platelet aggregates ${ }^{[7]}$. The patients with coronary slow flow have increased platelet activity compared to control subjects with normal coronary flow ${ }^{[8]}$. We therefore suggest that sP-selectin could be added as a possible biomarker to identify patients at cardiovascular risk.

\section{MATERIALS AND METHODS}

Our study was a case control study, where all patients underwent cardiac catheterization for suspected coronary artery disease. The study was conducted in Zagazig - University Hospitals in clinical pathology department and catheterization laboratory from May 2017 till January 2018. We have two groups: Group1 (patients group): Patients with primary coronary slow flow phenomenon $=$ 36 patients. Mean age of cases $49.33 \pm 4.99$ years with range of (34-55) years .In patients group there was 24 male and 12 female with a male to female ratio 2:1. Group II (control group): Patients with normal coronary angiography $=36$ patients. Mean age in control group $51.44 \pm 3.36$ years with range of (43-55) years. In control group there was 20 male and 16 female .

\section{Inclusion criteria:}

- Approval to share in the study

- angiographically proven slow coronary flow

- Age from $>18$ years old.

Exclusion criteria:

- Patient refusal.

- Local or systemic infection,

- previous history of infection,

- Malignancy.

- known inflammatory or immunological disease.

- previous history of myocardial infraction.

- left ventricular dysfunction.

All patients were subjected to:

- $\quad$ Thorough history taking and physical examination stress on(history of smoking ,chest pain ,Daibetus mellutus,Hypertension)

- Laboratory Investigation:

A- Sample collection;

Blood samples were collected from patients and controls after an overnight fasting for 12 h. A total of $8 \mathrm{ml}$ blood was collected from each subject. Fresh EDTA blood $(2 \mathrm{ml}$ of blood transferred to K2 EDTA $3.6 \mathrm{mg}$ vacutainer tube) was used for the assay of platelet activation , $(2 \mathrm{ml}$ of fresh blood samples were transferred to plain vacutainer tubes for assay of biochemical parameters and the rest of blood sample transferred to EDTA vacutainer for CBC examination.

\section{$B$ - Routine laboratory investigation}

- $\quad$ Complete blood picture including, $\mathrm{Hb}$ level, differential white blood cell and platelet count using Cobas Hitachi 8000(Roche) system.

- $\quad$ serum glucose level and Complete lipid panel including (TC ,LDL ,HDL , Triglyceride) by Cobas 8000 system (Roche) after an overnight fasting.

\section{3-immunophenotyping of platelets activation(p selectin CD62p)}

To minimize platelets activation during blood collection, we needed to use minimal stasis and large needle.

Blood was collected on $\mathrm{k}$ EDTA or sodium citrate vaccutianers .Fresh platelets rich plasma (PRP) samples (within less than 2hours ) were collected and appropriately diluted phosphate buffer saline (PBS)(1:1).

CD62p ( $p$ _selectin , GMP -1 leo) is a membrane glycoprotein in alpha granules of platelets.CD62p monoclonal antibody (MO $\mathrm{Ab}$ ) purchased from NEW TEST company from Alexandria.

CD626 MOAb was labeled with phycoerythrin(PE). Platelets activation was performed using FACS scan flowcytometry (Becton Dickinson, San Jose, CA,USA) based on the protocol described by Michelson (1999) with some modifications. Briefly .10 micron of MO Ab (cd62p) added to 100 micron of diluted sample, after gentle mixing sample were incubated for 15 minute in dark at room temperature then washed twice with $2 \mathrm{ml}$ PBS (5 min at $1500 \mathrm{rpm}$ ). The cell pellet was then resuspended in 500 micron of PBS. No fixative or lysing solution was used during the staining procedure.

Data acquisition was performed using CellQuest software (BD). Acquisition was done at Low flow speed and 10,000 events in the platelets region acquired .The forward 
and the side scatter (FSC/SSC) were set at logarithmic amplification and platelets were detected at the centered of the dot plot. For analysis, a gate was set around platelets population in the FSC/SSC dot plot then gated population was used to calculate the percentage of platelets positive for CD62p.

RESULTS

Table 1 Demographic data and chronic disease of studied group:

\begin{tabular}{|c|c|c|c|c|c|c|}
\hline & $\begin{array}{r}\text { Angi } \\
g\end{array}$ & $\begin{array}{l}\text { control } \\
\text { (36) }\end{array}$ & PCS & 36) & $\chi^{2}$ & $P$ value \\
\hline & $\mathrm{n}$ & $\%$ & $\mathrm{n}$ & $\%$ & & \\
\hline $\begin{array}{l}\text { Gender } \\
\text { Male } \\
\text { Female }\end{array}$ & $\begin{array}{l}20 \\
16\end{array}$ & $\begin{array}{l}55.6 \\
44.4\end{array}$ & $\begin{array}{l}24 \\
12\end{array}$ & $\begin{array}{l}66.7 \\
33.3\end{array}$ & 0.935 & 0.334N.S \\
\hline $\begin{array}{l}\text { Age(years) } \\
x \pm \text { SD } \\
\text { (range) } \\
\end{array}$ & & $\begin{array}{l}3.36 \\
5) \\
\end{array}$ & & & 1.109 & $0.271 \mathrm{~N} . \mathrm{S}$ \\
\hline $\begin{array}{l}\text { Diabetes mellitus } \\
\text { Absent } \\
\text { Present }\end{array}$ & $\begin{array}{l}20 \\
18 \\
\end{array}$ & $\begin{array}{r}55.6 \\
44.4 \\
\end{array}$ & $\begin{array}{l}17 \\
19 \\
\end{array}$ & $\begin{array}{l}47.2 \\
52.8 \\
\end{array}$ & 0.5 & 0.479 N.S \\
\hline $\begin{array}{l}\text { Hypertension } \\
\text { Absent } \\
\text { Present }\end{array}$ & $\begin{array}{l}16 \\
20\end{array}$ & $\begin{array}{l}44.4 \\
55.6\end{array}$ & $\begin{array}{l}20 \\
16\end{array}$ & $\begin{array}{l}55.6 \\
44.4\end{array}$ & 0.889 & 0.346 N.S \\
\hline $\begin{array}{l}\text { Family history } \\
\text { Absent } \\
\text { Present }\end{array}$ & $\begin{array}{l}19 \\
17 \\
\end{array}$ & $\begin{array}{l}52.8 \\
47.2 \\
\end{array}$ & $\begin{array}{l}18 \\
18 \\
\end{array}$ & $\begin{array}{l}50 \\
50 \\
\end{array}$ & 0.056 & 0.814 N.S \\
\hline $\begin{array}{l}\text { Smoking } \\
\text { Absent } \\
\text { Present }\end{array}$ & $\begin{array}{l}21 \\
15\end{array}$ & $\begin{array}{l}58.3 \\
41.7\end{array}$ & $\begin{array}{l}18 \\
18\end{array}$ & $\begin{array}{l}50 \\
50\end{array}$ & 0.503 & 0.478 N.S \\
\hline
\end{tabular}

this table show that there is statistically non_significant differences between group 1(PCSF)and group 2(normal coronary angio) regarding age , gender,DM,HPN.family history and smoking.

Table 2 CBC findings among studied groups:

\begin{tabular}{|l|c|c|c|c|}
\hline & $\begin{array}{c}\text { Angio free control } \\
\text { group(36) }\end{array}$ & PCSF group(36) & t test & P value \\
\hline $\begin{array}{l}\text { Hemoglobin(g/dl) } \\
\mathrm{X} \pm \text { SD } \\
\text { (range) }\end{array}$ & $\begin{array}{c}12.58 \pm 1.53 \\
(10.1-15)\end{array}$ & $\begin{array}{c}13.39 \pm 1.48 \\
(10.8-16.5)\end{array}$ & -2.301 & $0.024 \mathrm{~S}$ \\
\hline $\begin{array}{l}\text { WBCs }\left(\mathbf{1 0}^{\mathbf{3})}\right. \\
\mathrm{X} \pm \mathrm{SD} \\
\text { median }(\text { range })\end{array}$ & $\begin{array}{c}6.91 \pm 1.69 \\
7.35(4.5-104.6)\end{array}$ & $\begin{array}{c}9.08 \pm 3.69 \\
8.35(4.8-25.7)\end{array}$ & -3.201 & $0.002 * *$ \\
\hline $\begin{array}{l}\text { Platelet }\left(\mathbf{1 0}^{\mathbf{3})}\right. \\
\mathrm{X} \pm \mathrm{SD}\left(* 10^{3}\right) \\
\text { median }(\text { range })\left(* 10^{3}\right)\end{array}$ & $237.11 \pm 37.39$ & $227.42 \pm 33.26$ & -0.571 & $0.57 \mathrm{~N} . \mathrm{S}$ \\
\hline
\end{tabular}

There is statistically significant difference between both groups regarding hemoglobin level (g/dl). There is highly statistically significant difference between both groups regarding Total leucocytic count $\left(\mathbf{1 0}^{\mathbf{3}}\right)$. There is no is statistically significant difference between both groups regard platelets count $\left(\mathbf{1 0}^{\mathbf{3}}\right)$. 
Table 3 Fasting serum glucose ( $m g / d l)$ and (TC,LDL .HDL. Triglycerides, $m g / d l)$ among studied groups;

\begin{tabular}{|l|c|c|c|c|}
\hline & $\begin{array}{c}\text { Angio free control } \\
\text { group(36) }\end{array}$ & PCSF group(36) & t test & P value \\
\hline $\begin{array}{l}\text { Glucose(mg/dl) } \\
\text { X } \pm \text { SD } \\
\text { (range) }\end{array}$ & $\begin{array}{c}106.9 \pm 10.45 \\
(83-120)\end{array}$ & $\begin{array}{c}111.84 \pm 15.28 \\
(82-137)\end{array}$ & -1.6 & $0.114 \mathrm{~N} . \mathrm{S}$ \\
\hline T cholesterol & $\begin{array}{c}164.66 \pm 34.14 \\
(108.5-220)\end{array}$ & $\begin{array}{c}186.31 \pm 25.3 \\
(129.8-244)\end{array}$ & -3.058 & $0.003 * *$ \\
\hline $\begin{array}{l}\text { LDL c (mg/dl) } \\
\text { X } \pm \text { SD } \\
\text { (range) }\end{array}$ & $\begin{array}{c}117.42 \pm 34.54 \\
(58.2-178)\end{array}$ & $\begin{array}{c}138.22 \pm 24.12 \\
(88.9-185)\end{array}$ & -2.962 & $0.004 * *$ \\
\hline HDL c (mg/dl) & $\begin{array}{c}45.55 \pm 6.4 \\
\text { X } \pm \text { SD } \\
\text { (range) }\end{array}$ & $\begin{array}{c}48.09 \pm 10.46 \\
(25.9-68.1)\end{array}$ & -1.241 & $0.220 \mathrm{~N} . S$ \\
\hline Triglycerides(mg/dl) & $\begin{array}{c}130.1-63) \\
\text { X } \pm \text { SD } \\
\text { (range) }\end{array}$ & $\begin{array}{c}129.18 \pm 41.81 \\
(72.1-222.1)\end{array}$ & 1.010 & $0.317 \mathrm{~N} . \mathrm{S}$ \\
\hline
\end{tabular}

This table shows there are statistically non-significant differences between both groups regarding fasting serum glucose. There is a highly statistically significant difference between both groups regarding LDL. There is no statistically significant difference between both groups regarding HDL and Triglycerides. There is high statistically significant differences between both regarding Total cholesterol.

Table 4 P-selectin value among studied groups:

\begin{tabular}{|l|c|c|c|c|}
\hline & $\begin{array}{c}\text { Angio free control } \\
\text { group(36) }\end{array}$ & PCSF group(36) & t test & P value \\
\hline P selectin & $8.08 \pm 2.54$ & $66.43 \pm 20.69$ & -16.799 & $<0.001^{* *}$ \\
$\mathrm{X} \pm$ SD & $(2.38-12.91)$ & $(36.6-87.23)$ & & \\
(range) &
\end{tabular}

This table shows that there is highly statistically significant difference between both groups regarding $\mathrm{P}$ selectin level.

Table 5 Relation between some risk factors and p selectin levels in study groups:

\begin{tabular}{|c|c|c|c|c|}
\hline & $\begin{array}{c}\text { Angio free } \\
\text { control } \\
\text { group }(36)\end{array}$ & $\begin{array}{c}\text { PCSF } \\
\operatorname{group}(36)\end{array}$ & t test & $P$ value \\
\hline & $\mathrm{x} \pm \mathrm{SD}$ & $\mathrm{x} \pm \mathrm{SD}$ & & \\
\hline $\begin{array}{l}\text { Gender } \\
\text { Male } \\
\text { Female }\end{array}$ & $\begin{array}{l}8.34 \pm 1.82 \\
7.74 \pm 3.27\end{array}$ & $\begin{array}{c}61.22 \pm 22.81 \\
76.84 \pm 9.78\end{array}$ & $\begin{array}{l}11.311- \\
-23.515\end{array}$ & $\begin{array}{l}<0.001 * * \\
<0.001 * *\end{array}$ \\
\hline \begin{tabular}{|l|} 
Diabetes \\
Absent \\
Present
\end{tabular} & $\begin{array}{l}8.64 \pm 2.38 \\
7.51 \pm 2.65\end{array}$ & $\begin{array}{l}64.28 \pm 18.98 \\
68.35 \pm 22.44\end{array}$ & $\begin{array}{l}-11.997 \\
-11.733\end{array}$ & $\begin{array}{l}<0.001 * * \\
<0.001 * *\end{array}$ \\
\hline $\begin{array}{l}\text { Hypertension } \\
\text { Absent } \\
\text { Present }\end{array}$ & $\begin{array}{c}8.51 \pm 2.5 \\
7.64 \pm 2.59\end{array}$ & $\begin{array}{c}66.29 \pm 17.95 \\
66.59 \pm 24.3\end{array}$ & $\begin{array}{l}-14.247 \\
-9.567 \\
\end{array}$ & $\begin{array}{l}<0.001 * * \\
<0.001^{* *}\end{array}$ \\
\hline $\begin{array}{l}\text { Hypercholesterolemia: } \\
\text { Absent } \\
\text { Present }\end{array}$ & $\begin{array}{l}7.85 \pm 2.59 \\
9.92 \pm 1.03\end{array}$ & $\begin{array}{l}72.64 \pm 12.02 \\
50.28 \pm 29.36\end{array}$ & $\begin{array}{l}-26.984 \\
-4.342 \\
\end{array}$ & $\begin{array}{c}<0.001 * * \\
0.002 * *\end{array}$ \\
\hline
\end{tabular}

There are highly statistically significant differences between gender, presence of diabetes, hypertension and hypercholesterolemia and p selectin level. 
Table 6 Correlation between p selectin level and some laboratory parameters among (PCSF group)

\begin{tabular}{|c|c|c|}
\hline & (PCSF group) & \\
\hline & $\mathbf{r}$ & $\mathbf{p}$ \\
\hline Age (years) & 0.012 & 0.943 \\
\hline Hemoglobin (g/dl) & -0.338 & $0.044 * \mathrm{~S}$ \\
\hline WBCs $\left(x 10^{3}\right)$ & -0.137 & 0.427 \\
\hline Platelets $\left(\mathbf{x 1 0}^{3}\right)$ & -0.289 & 0.088 \\
\hline Glucose (mg/dl) & -0.073 & 0.672 \\
\hline LDL cholesterol (mg/dl) & -0.239 & 0.16 \\
\hline HDL cholesterol (mg/dl) & -0.31 & 0.066 \\
\hline Triglycerides (mg/dl) & 0.041 & 0.812 \\
\hline Total cholesterol (mg/dl) & -0.356 & $0.033 * \mathrm{~S}$ \\
\hline
\end{tabular}

Among cases, there are significant negative correlation between p selectin, haemoglobin level $(\mathrm{g} / \mathrm{dl})$ and Total cholesterol level(mg/dl)

Table 7 Comparison of TIMI frame count Among study groups.

\begin{tabular}{|l|c|c|c|c|}
\hline & $\begin{array}{c}\text { Angio free control } \\
\text { group(36) }\end{array}$ & PCSF group(36) & t test & P value \\
\hline $\begin{array}{l}\text { LADc } \\
\mathrm{x} \pm \mathrm{SD}\end{array}$ & $24.62 \pm 3.06$ & $55.72 \pm 5.62$ & -27.61 & $<0.001 * *$ \\
\hline $\begin{array}{l}\text { CFX } \\
\mathrm{x} \pm \mathrm{SD}\end{array}$ & $30.13 \pm 32.3$ & $49.71 \pm 3.64$ & $5.977-$ & $<0.001 * *$ \\
\hline $\begin{array}{l}\text { RCA } \\
\mathrm{x} \pm \mathrm{SD}\end{array}$ & $22.76 \pm 2.95$ & $52.61 \pm 5.22$ & -29.31 & $<0.001 * *$ \\
\hline $\begin{array}{l}\text { Mean } \\
\mathrm{x} \pm \mathrm{SD}\end{array}$ & $23.57 \pm 2.73$ & $52.66 \pm 4.01$ & -33.42 & $<0.001 * *$ \\
\hline
\end{tabular}

There are highly significant difference in ( LADc ,CFX,RCA and mean TIMI frame count) among study group.

Table 8 Correlation between p selectin level and TIMI frame count among cases.

\begin{tabular}{|l|c|c|}
\hline \multirow{2}{*}{\multicolumn{1}{c|}{}} & \multicolumn{2}{|c|}{ Cases } \\
\cline { 2 - 3 } & $\mathbf{r}$ & P value \\
\hline LADc TFC & 0.482 & $0.003^{*} \mathrm{~S}$ \\
\hline RCA TFC & 0.012 & $0.945 \mathrm{~N} . \mathrm{S}$ \\
\hline Mean TFC & 0.473 & $0.004^{*} \mathrm{~S}$ \\
\hline
\end{tabular}

This table shows that there is significant positive correlation between $p$ selectin and LAD cTFC (left anterior descending artery TIMI frame count) and there is non-significant correlation between $p$ selectin and CFX TFC (circumflex artery TIMI frame count). There is significant positive correlation between $\mathrm{p}$ selectin and

\begin{tabular}{|l|l|l|l|l|l|l|l|l|l|}
\hline Cutoff & AUROC & Sensitivity & Specificity & PPV & NPV & +LR & -LR & accuracy & p \\
\hline 10.945 & 0.972 & 94.4 & 88.9 & 89.5 & 94.1 & 8.5 & 0.06 & 91.7 & $<0.001^{* *}$ \\
\hline
\end{tabular}

\section{DISCUSSION}


phenomenon (PCSF) is an angiographic clinical entity, characterized by delayed distal vessel opacification in the absence of significant epicardial coronary stenosis.(8)

PCSF has direct clinical implications, as it has been linked to clinical manifestations of myocardial ischemia, life-threatening arrhythmias, sudden cardiac death, and recurrent acute coronary syndromes.(9)

Platelets play important role in the pathogenesis of atherosclerotic complications, contributing to thrombus formation after plaque rupture Following platelet stimulation.(10)

Platelet activation in patients with slow coronary flow remains to be largely unknown. Increased platelet activity in that patient group might be partially responsible for the development of acute coronary syndromes.(11)

Platelets activation may be enhanced in the presence of micro vascular dysfunction or slow flow, including high shear stress and impairment of the endothelial barrier.(12)

$\mathrm{P}$-selectin is constitutively expressed in the a-granules of platelets and the WeibelPalade bodies of endothelial cells, with a soluble form present in the plasma.(13)

Following platelet stimulation, P-selectin becomes expressed on the platelet surface where it is rapidly shed. This shedding from platelets is thought to be the main source of the soluble form found in plasma following thrombotic events and which may have its own physiological activity.(14)

We tested the hypothesis that increased platelet activation may be present in patients with slow coronary flow (PCSF) and may contribute to the pathogenesis of primary coronary flow phenomenon (PCSF).

Our study was conducted in clinical pathology department and catheterization lab in Zagazig University hospitals to assess role of P SELECTIN in coronary slow flow. On 72 individual. Group I (Primary coronary slow flow);36 case and Group II (Normal coronary angiography), 36 controls.

In this study regard CBC there is statistical significant difference in Hemoglobin level (g/dl) between both groups this was hand in hand with Singhal et al. who concluded that $\mathrm{Hb}$ increased the expression of P-selectin (secreted by $\alpha$-granules upon platelet activation) in a concentration-dependent manner.

In this study the Total leucocyte count (TLC) is statistically significant different in PCSF than NCA, this is agree with Altunka et al. who found that there is significant difference between PCSF and agnio free controls.

As regaerd to platelets There was no statistical significance difference between both group. This was agree with Y1lmaz et al. and disagree with Akboğa et al. where was higher TLC and platelets as there was positive correlation between them and CRP which indicate systemic inflammation but we exclude inflammation from our study.

Glucose in our study, there was no statistical significant difference between both groups, this was agree with Doğan et al. and disagree and disagree with Signori et al. due to increase incidences of metabolic syndrome in their study.

In our study, there was highly statistical significant difference between both groups regard LDL this was agree with Guo et al. who found high LDL $(\mathrm{mg} / \mathrm{dl})$ level in PCSF patients compared to controls. We found that there was no significant statistical difference between both group as regard HDL this was agree with Demir et al. this may genetic features of the both groups.

Regard Triglyceride there was no significant statistical difference between both group, this was agree with Doğan et al. and hand in hand with Yilmaz et al. he referred this due eating habits of the same country.

In our study $T$. cholestrol was significant statistically different between both group this was in agreement with George et al. and disagree with Doğan et al. this might due to different method enzymatic-colorimetric assay.

Regard P-selectin in our study there was highly statistical significance difference between both groups. This was agree with Celik et al. and disagree with Gurbel et al. they stated that the platelet expression of $\mathrm{P}$ selectin is unrelated to the level found in plasma in patients with acute chest pain this might due to different determination method as they used ELISA. 
Among cases There is highly statistical difference between gender and $P$ SELECTIN.

In this study there is non-significant positive correlation between $\mathrm{P}$ selectin and age this was agree with George et al.

In our study among there was significant negative correlation between P SELECTIN and hemoglobin this is agree with Singhal as they found that $\mathrm{Hb}$ increased the expression of P-selectin (secreted by $\alpha$-granules upon platelet activation) in a concentrationdependent manner .

In our study there was non-significant negative correlation between $\mathrm{p}$ selectin and TLC (Total leucocyte count) this was agree with Ebeid et al. this was disagree with Aref et al. where they found positive significant correlation with $\mathrm{P}$ SELECTIN as control group were complete clinicaly free In this study there was negative non-significant correlation between $\mathrm{p}$ selectin and platelet count.

In this study there was negative correlation between $p$ selectin and LDL cholesterol this was in agreement with Chan et al. where they found incubation of HDL-C and oxidized LDL (ox-LDL) with platelets led to inhibition of the increased number of $\mathrm{P}$ selectin receptors induced by ox-LDL this was disagree with Ridker et al. as they measured them in patients with CAD and patients with metabolic syndrome.

We found that there was non-significant negative correlation between $\mathrm{p}$ selectin and HDL cholesterol. Guo who found nonsignificant correlation between $\mathrm{P}$ selectin and HDL.

In this study there was significant positive correlation between RCA TFC(right coronary artery TIMI frame count ) and $\mathrm{p}$ selectin this was agree with Akboğa et al. and Pawelczyk et al. In this study there was significant positive correlation between mean TIMI frame count and $\mathrm{p}$ selectin this was in agreement with Demir et al. and Akboğa et al. there was non-significant correlation between $\mathrm{P}$ selectin and CFX TFC(circumflex coronaty artery TIMI frame count).

In this study when a ROC curve was generated to determine $\mathrm{P}$ selectin level in PCSF patients the area under the curve
(AUC) was 0.972 The best cutoff value of $\mathrm{P}$ selectin in detection of slow coronary flow is $\geq 10.945$ with sensitivity $94.4 \%$, specificity 88.9, PPV 89.5, NPV 94.1, +LR 8.5, -LR 0.06 . The accuracy of the test is 91.7 $(\mathrm{p}<0.001)$. The current study demonstrated that sP-selectin levels of the patients with slow coronary flow were found to be significantly higher compared to those of the subjects with normal coronary flow. Besides, significant positive correlations were detected between mean TIMI frame counts and sP-selectin level.

Yetkin et al. have found that patients with myocardial infarction and normal coronary arteries have increased TIMI frame count, indicating the slow coronary flow; compared with subjects without myocardial infarction. They have suggested that SCFP might be the underlying cause of myocardial infarction in those patients.

The patients with coronary slow flow have increased platelet activity compared to control subjects with normal coronary flow. Although increased platelet activity may play a role in the pathogenesis of coronary slow flow.

\section{CONCLUSION}

In conclusion, the results of the present study revealed that there is very high statistically significant difference in $\mathrm{P}$-selectin level between group 1(primary coronary slow flow patients) and group 2 (normal coronary angio patients) and there is statistically significant association between P-selectin and TIMI frame count in coronary slow flow. We therefore suggest that $\mathrm{sP}$-selectin could be added as a possible biomarker to identify patients at cardiovascular risk.

\section{REFERENCES}

1. Arjmand, N. and Dehghani, M. (2016): Complete blood cell count components and coronary slowflow phenomenon. Therapeutics and Clinical Risk Management, 12(1): 1827-1829

2. Barbaux, S., Poirier, O., Pincet, F., Hermand, P., Tiret, L. and Deterre, P. (2010): The adhesion mediated by the P-selectin P-selectin glycoprotein ligand-1 (PSGL-1) couple is stronger for shorter PSGL-1 variants. Journal of Leukocyte Biology, 87(4): 727-734.

3. Cleator, J. (2006): Differential regulation of endothelial exocytosis of P-selectin and von Willebrand factor by protease-activated receptors and cAMP. Blood, 107(7): 2736-2744. 
4. Heusch, G. (2016): Myocardial Ischemia. Circulation Research, 119(2): 194-196.

5. Hui, H., Fuller, K., Erber, W. and Linden, M. (2014): Measurement of monocyte-platelet aggregates by imaging flow cytometry. Cytometry Part A, 87(3): 273-278.

6. Mutar, M. (2016): Risk Factors and Angiographic Findings in Patients with LBBB Who Underwent Coronary Angiography in Duhok Heart Center. Journal of Medical Science And clinical Research, 04(11): 14112-14117.

7. Wang, X. and Nie, S. (2011): The Coronary Slow Flow phenomenon: Characteristics, mechanisms and implications. Cardiovasc Diagn Ther., 1: 3743.

8. Baroopal, A., Sanghvi, S. and Mathur, R. (2017): Clinical, demographic, risk factor and angiographic profile of coronary slow flow phenomenon: A single centre experience. Indian Heart Journal, 69: pp.S39-S40.

9. Wang, X. and Nie, S. (2011): The Coronary Slow Flow phenomenon: Characteristics, mechanisms and implications. Cardiovasc Diagn Ther., 1: 3743

10. Badimon, L. and Vilahur, G. (2014): Thrombosis formation on atherosclerotic lesions and plaque rupture. Journal of Internal Medicine, 276(6): 618632

11.Assinger, A., Buchberger, E., Laky, M., Esfandeyari, A., Brostjan, C. and Volf, I. (2011): Periodontopathogens induce soluble P-selectin release by endothelial cells and platelets. Thrombosis Research, 127(1).

12-Altunkas, F., Koç, F., Çelik, A., Kayihan, K., Karayakali, M. and Ceyhan, K. (2014): Coronary slow flow phenomenon and neutrophil-tolymphocyte ratio. Atherosclerosis, 235(2): 215

13-Akboğa, M.K., Canpolat, U., Balc1, K. G., Akyel, A., Şen, F., Yayla, Ç. and Aydoğdu, S. (2015): OP065 Increased Platelet-to-Lymphocyte Ratio is Related to Slow Coronary Flow. The American Journal of Cardiology, 115: S28-S29.

14-Yılmaz, M., Dağlı, M., Uku, Ö, Bilen, M., Korkmaz, H., Erdem, K. and Kurtoğlu, E. (2017): Focusing on a complete blood cell parameter: mean platelet volume levels may be a predictor of coronary slow flow. Vascular Health and Risk Management, 13(1): 255-261

15- Doğan, M., Akyel, A., Çimen, T., Bilgin, M., Sunman, H., Kasapkara, H., Arslantaş, U., Yayla, K., Açıkel, S. and Yeter, E. (2013): Relationship Between Neutrophil to Lymphocyte Ratio and Slow Coronary Flow. Clinical and Applied Thrombosis/Hemostasis, 21(3): 251-254.

16-Signori, L., Quadros, A., Sbruzzi, G., Dipp, T., Lopes, R. and Schaan, B. (2012): Endothelial function in patients with slow coronary flow and normal coronary angiography. Clinics, 67(6): 667680
17-Guo, L., Sun, G., Wang, G., Ning, W. and Zhao, K. (2014): Soluble P-selectin promotes acute myocardial infarction onset but not severity. Molecular Medicine Reports, 11(3): 2027-2033.

18-Demir, M., Cosar, S. and Melek, M. (2014): Evaluation of plasma eosinophil count and mean platelet volume in patients with coronary slow flow. Clinics, 69(5): 323-326

19-George, R., Bhatt, A., Narayani, J., Thulaseedharan, J., Sivadasanpillai, H. and Tharakan, J. (2016): Enhanced P-selectin expression on platelet-a marker of platelet activation, in young patients with angiographically proven coronary artery disease. Molecular and Cellular Biochemistry, 419(1-2): 125-133.

20-Celik, T., Yuksel, U., Bugan, B., Iyisoy, A., Celik, M., Demirkol, S., Yaman, H., Kursaklioglu, H., Kilic, S. and Isik, E. (2009): Increased platelet activation in patients with slow coronary flow. Journal of Thrombosis and Thrombolysis, 29(3): 310-

21-Gurbel, P.A., Kereiakes, D.J. and Serebruany, V.L. (2000): Soluble P-selectin is not a surrogate marker for platelet P-selectin: Evidence from a multicenter chest pain study group. J. Thromb. Thrombolysis, 10(1): 15-22

22-Ebeid, S., Sadek, N., El-Benhawy, S. and Mahmoud, G. (2014): Plasma substance P and soluble P-selectin as biomarkers of $\beta$-thalassemia induced hypercoagulability. Alexandria Journal of Medicine, 50(2): 107-111

23-Aref, S., Sakrana, M., Hafez, A. and Hamdy, M. (2005). Soluble P-selectin levels in Diabetes mellitus patients with coronary artery disease. Hematology, 10(3): 183-187.

24-Chan, L., Luo, X., Ni, H., Shi, H., Liu, L., Wen, Z. and Li, J. (2015): High levels of LDL-C combined with low levels of HDL-C further increase platelet activation in hypercholesterolemic patients. Brazilian Journal of Medical and Biological Research, 48(2): 167-173.

25-Ridger, V., Hellewell, P. and Norman, K. (2005): Land P-Selectins Collaborate to Support Leukocyte Rolling in Vivo When High-Affinity P-Selectin-PSelectin Glycoprotein Ligand-1 Interaction Is Inhibited. The American Journal of Pathology, 166(3): 945-

26-Yetkin, E., Turhan, H., Erbay, A., Aksoy, Y. and Senen, K. (2005): Increased thrombolysis in myocardial infarction frame count in patients with myocardial infarction and normal coronary arteriogram: a possible link between slow coronary flow and myocardial infarction. Atherosclerosis, 181(1): 193-199.

27-Pawelczyk, M., Kaczorowska, B. and Baj, Z. (2017): The impact of hyperglycemia and hyperlipidemia on plasma P-selectin and platelet markers after ischemic stroke. Archives of Medical Science, 5(1): 1049-1056

How to cite this article: El-Attar NI, Assal AM, Amin ME, Sleem RMS. Role of P-selectin in patients with slow coronary flow. ZUMJ 2019; 25 (1): 101-108. 
